Agropedology 2016, 26 (01), 69-78

\title{
Land Suitability Evaluation for Rice (Oryza sativa L.) in Tirora Tehsil of Gondia District, Maharashtra - A GIS Approach
}

\author{
Vishakha Dongare', A. K. Maji, G. P. Obi Reddy, I.K. Ramteke ${ }^{2}$ \\ ${ }^{I} I C A R$ - National Bureau of Soil Survey \& Land Use Planning, Nagpur - 440033. \\ ${ }^{2}$ Maharashtra Remote sensing Application Centre, Nagpur.
}

\begin{abstract}
In the present study, land suitability evaluation has been carried out for rice in Tirora tehsil of Gondia district, Maharashtra, through analysis of landforms and soils using IRS-ID LISS-III and ancillary data Geographic Information System (GIS). Thirteen distinct landform units have been delineated in the area. The slope of the tehsil varied from level to nearly level $(0-1 \%)$ to very steep slopes $(>50 \%)$. The soils occurring on different land form units been studied and horizons wise soil samples were characterized and classified. The soil depth varied from very shallow $(10-25 \mathrm{~cm})$ to very deep $(>150 \mathrm{~cm})$ and soil texture ranged from clay loam to clay depending upon topographic positions. The land evaluation criterion of FAO has been followed to assess the land suitability for rice. The suitability analysis indicates that about $45.5 \%$ of total geographical area (TGA) is highly suitable, $24 \%$ is moderately suitable and $24.2 \%$ o is not suitable for rice cultivation in the tehsil.
\end{abstract}

Keywords: GIS, Landforms, , Land suitability, Rice, Soils, Tirora

\section{Introduction}

In order to meet the increasing demand of food for the ever growing population on the planet, crops need to be grown in areas where they are best suited. To achieve it, systematic soil resource inventory is essential and survey information need to be analyzed and integrated using the advanced tools like Geographical Information System (GIS) to assess crop suitability for different crops. Many attempts have been made in characterization of soil resources using remotely sensed data in parts of basaltic terrain (Saxena et al. 2000; Srivastava and Saxena, 2004; Reddy et al. 2013). Vishakha et al. (2013) establishes landform and soil relationship in a geologically complex terrain of Tirora tahsil of Gondia district, Maharashtra using remotely sensed data and GIS techniques. Maji et al. (2002) carried out soil resource inventory of Nagaland state of North-eastern Himalaya region. Data generated form soil survey and laboratory analysis was subsequently used to develop spatial database in GIS for soil and analysis of thematic information. Maji and Krishna (1996) described the use of GIS in soil survey and cited the capabilities of GIS, such as reclassification techniques, for thematic map generation and criterion based analysis for soil suitability evaluation.

*Corresponding Author Email: d.vishu@rediffmail.com, d.vishakha@yahoo.co.in
Land suitability analysis is the pre-requisite in order to achieve higher productivity and to meet the demand for food (Kihoro et al. 2013). Land evaluation is a scientific procedure to assess the potential and constraints of a given land parcel for agricultural purposes (Rossiter, 1996). The analysis allows identification of the main limiting factors of crop production and enables decision makers to develop crop management system (Halder 2013). Soil qualities, based on one or more land characteristics are important for developing a suitable land use plan (FAO 1976). Eswaran et al. (1993) considered soil qualities like nutrient availability, effective soil volume, soil erodibility, soil depth, texture, slope condition and $\mathrm{pH}$ as important parameters for sustainable land use planning. The FAO (1976) framework for land suitability involves the construction of matching tables or transfer functions, and subsequent calculations of suitability. However, automating the FAO procedures, routine errors could be minimized (Davidson et al. 1994; Rossiter, 1990). With advances in computers processing technology, in the recent past many computer- based decision support tools and techniques have been developed in land suitability analysis (Burrough 1989; Baja et al. 2002; Walke et al. 2012).

Land suitability mapping and an analysis is one of the most useful applications of GIS for spatial planning and management (Malczewski, 2004; Bin et al. 2007). Zink and 
Valenzuela (1990) showed application of ILWIS software for agricultural data interpretations. Maji (1992, 1992a) carried out land evaluation for multiple land utilization types using Automated Land Evaluation Systems (ALES). Land evaluation using AGROMA software has been demonstrated by Maji et al. (2005). Bobade et al. (2010) used GIS based techniques to assess the land use suitability in Seoni District of Madhya Pradesh. Dengiz (2013) developed a spatial model for land suitability assessment for rice using GIS in Central Anatolian region of Turkey. Gangopadhyay et al. (2010) evaluated land resources of Peruguda microwatershed from semi arid tropics of Ranga Reddy district of erstwhile Andhra Pradesh based on the visual interpretation of IRS-1C LISS III fused with PAN data (1:12,500 scale) and field surveys. Reddy et al. (2004) evaluated the land resources in a part of Eastern Maharashtra Plateau using remote sensing and GIS for cotton suitability. In the present study, an attempt has been made to evaluate the land resources of Tirora Tehsil, Gondia district, Maharashtra for rice using IRS-ID LISS III data and GIS techniques.

\section{Geographical setting of the study area}

Tirora tehsil of Gondia district is bounded by North latitudes $21^{\circ} 13^{\prime} 05^{11}$ to $21^{\circ} 33^{\prime} 30^{11}$ and East longitudes $79^{\circ} 47^{\prime}$ $50^{11}$ to $80^{\circ} 05^{\prime} 00^{11}$ and is located in North Western part of the district, Maharashtra with total geographical area of 617.10 Sq.km. Climate of the study area is sub-humid, sub-tropical with well defined summer (March - May), rainy season (June - October) and mild winter (November - February). The mean annual temperature is $26.4^{\circ} \mathrm{C}$ with a mean maximum of $29.3^{\circ} \mathrm{C}$ and mean minimum of $24.12^{\circ} \mathrm{C}$. The mean annual precipitation of the tehsil is $1400 \mathrm{~mm}$ of which nearly $85 \%$ is received during south-west monsoon period (June-October). Wainganga river flows from north to south in the western part of the tehsil forms a major drainage system having the lower elevation ranges from 240 to 280 above MSL, whereas, the higher elevation ranges from 350 to 500 above MSL.

\section{Material and Methods}

In the present study, Geocoded IRS-ID LISS III standard False Colour Composite (FCC) of $8^{\text {th }}$ March 2000 (Path 100, Row 57) generated from bands 4,3 and 2 have been used in conjunction with Survey of India (SOI) topographical sheets on 1:50,000 scale for generation of base map and delineation of distinct landforms. Slope map was prepared using contour information generated from SOI toposheets and subsequently corrected based on ground truth data. The locations for representative soil profiles were identified in each landform unit. Soil profiles were studied for morphometric characteristics and horizon-wise soil samples (processed one) physical and chemical characteristics following standard analytical methods (Jackson 1973). Soils were classified according to Soil Taxonomy (Soil Survey Staff 1999). Spatial database in GIS pertaining to length of growing period (LGP), slope, soil drainage, soil depth, particle-size classes, $\mathrm{pH}$ status, salinity and surface stoniness have been generated following standard procedure in GIS to use in land suitability analysis.

\section{Land Suitability Evaluation Using GIS}

In AGROMA GIS software, the processes / suitability - mapping option was selected and model was built to evaluate the land resources for rice. The classes in layer were distinguished based on their characteristics for rice crop. In land suitability evaluation, the software allows to combine the thematic area, quadtrees and raster in the model. Knowledge based scores were assigned for input thematic layers in GIS based crop suitability model to define their suitability or lack thereof. Scores to the classes were assigned to represent an assessment of relative suitability. A weightage is a value that defines the relative importance of the parameter in the analysis and final output. The higher the weightage value, the more influence the associated parameter will exert in analysis. Suitability mapping will allow ranking this variable with greater importance than other variables. Based on the relative importance of the class in each layer, the relative suitability class was assigned through suitability ranking scheme (Tables 3 and 4). AGROMA GIS uses the following relative scale to classify an area's suitability for agriculture $i e$,. highly suitable, moderately suitable, marginally suitable, negligible suitability, and not suitable.

Initially ranks have been assigned for each class in the input layers. After suitability ranking was completed for each class in input layer, the suitability weightages were assigned to the layers considered. Based on the knowledgebased criteria, higher weightage was assigned to the thematic data layer of significant influence on land suitability for rice than the others. For example, soil depth, slope and LGP are the most crucial factors for rice cultivation. Hence, these layers were assigned a higher weightage than other input 
layers. The suitability weightages are displayed with a default weighting system and AGROMA GIS uses the number 100 divided by the number of input layers to arrive at an identical default weight for each input. To start defining the derived weightage scheme of a thematic layer, new weightage values are assigned. The total of all suitability weights must be equal to 100 . After assigning the weights for layers and classes, the crop suitability model was executed in GIS and the cumulative value obtained in the model were categorized into highly suitable, moderately suitable, marginally suitable, negligible suitability and not suitable for rice cultivation.

\section{Results and Discussion}

\section{Soil site characteristics}

The geomorphic analysis reveals that the majority areas of the tehsil is under level to nearly level slopes (0-1\%) and are associated with shallow, moderate and deeply weathered pediments, in narrow valley and broad valley floors. The very gentle slopes (1-3\%) are associated mainly with shallow and deeply weathered pediments. The shallow weathered pediments are in association with gentle slopes (3-8\%). The moderate slopes $(8-15 \%)$ occupy mainly the shallow and moderately weathered pediments. The moderately steep slopes (15-30\%) are in association with linear ridges, isolated mounds, dissected hilltops and shallow weathered pediments (Table 1). The eastern part of the tehsil is under steep (30-50\%) to very steep slopes $(>50 \%)$ with dissected hills, narrow scarp slopes, linear ridges and subdued hills. The analysis of surface drainage shows that majority of the area is under well drained conditions. The study reveals that nearly $30.1 \%$ of the tehsil in the south-east and north-west parts is covered by moderately well drained soils. Well-drained soils are found in the western and eastern parts with an area of $63.8 \%$ of the tehsil. The analysis of surface texture shows that about $30.9 \%$ of the total geographical area (TGA) is covered by clay textured soils and nearly $28.9 \%$ of TGA is under clay loam soils. The sandy clay loam and sandy loam soils occupy nearly $18.7 \%$ and $15.5 \%$ of TGA, respectively.

\section{Physical characteristics}

The soils developed on isolated mounds and denuded plateau spurs are shallow $(<50 \mathrm{~cm})$. Upper and lower sectors of main valley-side slopes and narrow drainage floor have deep to very deep soils $(>100 \mathrm{~cm})$. Shallow soils are found on the upper elevated area and isolated mounds and this area poses major limitation of soil depth for cultivation of crops. Moderately deep soil is found in the eastern part of the tehsil. Deep to very deep soils are found at lower zone. Various depth classes of the area showed that $6.9 \%$ soils are very shallow $(10-25 \mathrm{~cm})$ to shallow $(25-50 \mathrm{~cm})$, which are in association with hummocky landforms. Nearly $11.6 \%$ of area is under moderately deep $(75-100 \mathrm{~cm})$ and very deep soils $(>100 \mathrm{~cm})$ occupying $75.4 \%$ of TGA mostly occurring on level to gently sloping lands and moderately plain regions. About $6.1 \%$ of the TGA is occupied by the water bodies in the tehsil.

The particle size distribution shows that majority of the soils have high amount of clay. (Table 1). Soils developed on shallow weathered pediments (Sk), moderately weathered pediments deeply weathered pediments and aggraded valley fills have higher clay content (49.2 to $64.2 \%)$ (Fig. 1$)$.

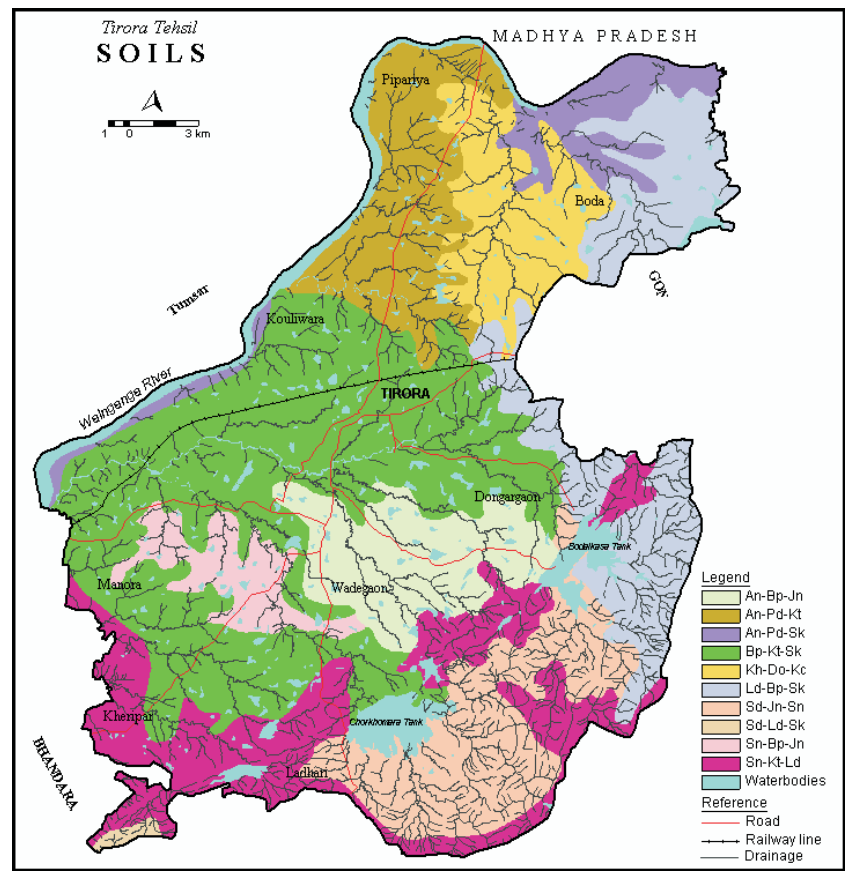

Fig.1 Soil map of Tirora tehsil

LGP ranged from high 150 to-180 days covering an area of $62.9 \%$. very high LGP (180-210 days) and extremely high LGP ( $>210$ days) were noticed in the northern, central and southern parts of the tehsil with an area of 16.8 and $14.2 \%$, respectively.

\section{chemical characteristics}

The $\mathrm{pH}$ of the soils ranged from 4.7 to 7.7 i.e, moderately acidic to slightly alkaline (Table 2 ). The results showed that soils developed on subdued hills, moderately pediment, dissected hills and linear ridges are moderately acidic (pH 5.2) and cover $15.5 \%$ area. Soils developed on moderately weathered pediments, linear ridges, dissected hills, shallow weathered pediments, deeply weathered pediments, moderately weathered pediments, 


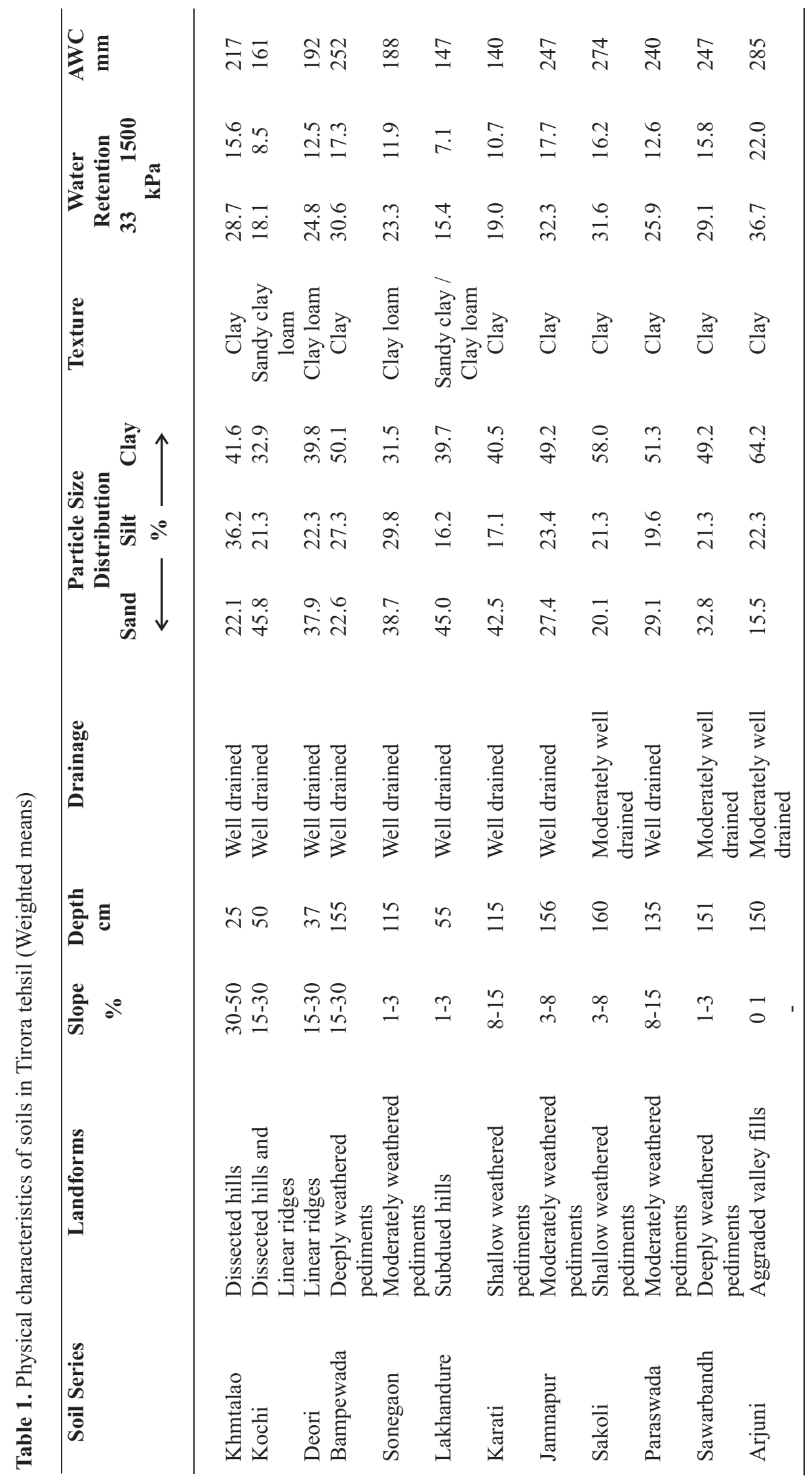




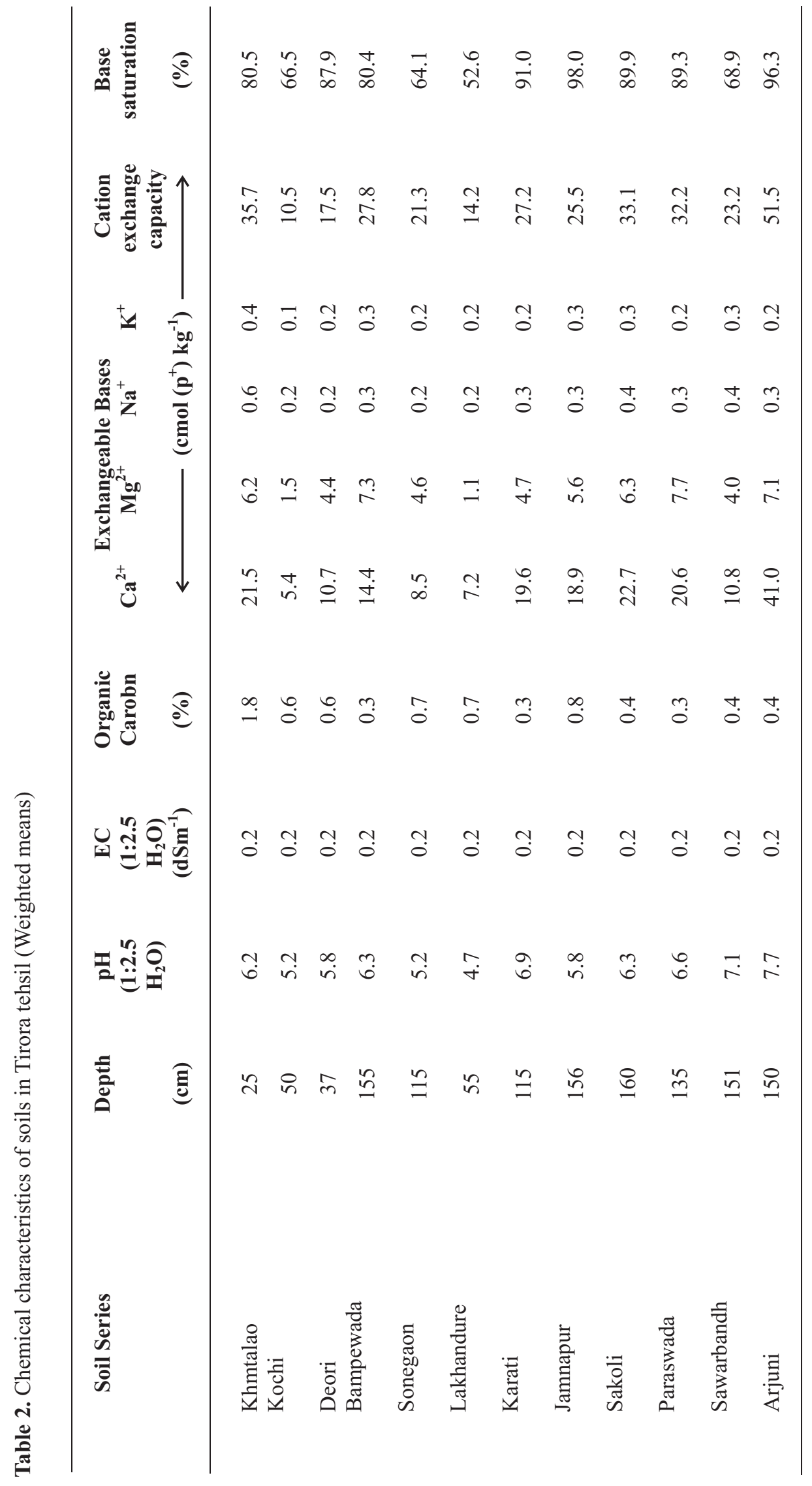


Table 3. Land suitability criteria for rice

\begin{tabular}{|c|c|c|c|c|c|}
\hline \multicolumn{2}{|c|}{ Land use requirement } & \multicolumn{4}{|c|}{ Rating } \\
\hline Land quality & Soil-site characteristic & $\begin{array}{l}\text { Highly } \\
\text { suitable, } \\
\text { S1 }\end{array}$ & $\begin{array}{l}\text { Moderately } \\
\text { suitable, S2 }\end{array}$ & $\begin{array}{l}\text { Marginally } \\
\text { suitable, } \\
\text { S3 }\end{array}$ & $\begin{array}{l}\text { Not suitable, } \\
\text { N }\end{array}$ \\
\hline $\begin{array}{l}\text { Temperature } \\
\text { regime }\end{array}$ & $\begin{array}{l}\text { Mean temperature in } \\
\text { growing season }\left({ }^{\circ} \mathrm{C}\right)\end{array}$ & $30-34$ & $34-38$ & $38-40$ & $>40$ \\
\hline LGP & & $>150$ & $120-150$ & $90-120$ & $<90$ \\
\hline $\begin{array}{l}\text { Oxygen } \\
\text { availability to } \\
\text { roots }\end{array}$ & Soil drainage (class) & $\begin{array}{l}\text { Imperfectly } \\
\text { drained }\end{array}$ & $\begin{array}{l}\text { moderately } \\
\text { well drained }\end{array}$ & $\begin{array}{c}\text { well drained; } \\
\text { somewhat } \\
\text { excessively } \\
\text { drained }\end{array}$ & $\begin{array}{l}\text { excessively } \\
\text { drained }\end{array}$ \\
\hline $\begin{array}{l}\text { Nutrient } \\
\text { availability }\end{array}$ & $\mathrm{CaCO}_{3}$ in root zone $(\%)$ & $<15$ & 15 to 25 & 25 to 30 & $>30$ \\
\hline Nutrient retention & Texture (class) & loamy & Fine loamy & fine & Loamy-skeletal \\
\hline $\begin{array}{l}\text { Rooting } \\
\text { conditions }\end{array}$ & Effective soil depth (cm) & $>75$ & 51 to 75 & 25 to 50 & $<25$ \\
\hline Soil toxicity & $\begin{array}{l}\text { Salinity (EC saturation } \\
\text { extract, dS m }{ }^{-1} \text { ) } \\
\text { Sodicity (ESP) }\end{array}$ & $\begin{array}{c}\text { Nil - } \\
\text { Negligible }\end{array}$ & Slight & - & - \\
\hline Erosion hazard & Slope (\%) & 0 to 3 & 3 to 8 & 8 to 15 & $>15$ \\
\hline
\end{tabular}

* Flooding is considered for rainfed rice. Source: A. Natarajan (pers. communication) 
Table 4. Soil-climatic suitability criteria for rice crop

\begin{tabular}{|c|c|c|c|c|}
\hline S. No. & Theme & Crop (rice) & Class & $\begin{array}{l}\text { Suitability class } \\
\text { (rice) }\end{array}$ \\
\hline \multirow{6}{*}{1} & \multirow{3}{*}{ LGP } & \multirow{3}{*}{15} & High (150-180) & S1 \\
\hline & & & Very high $(180-210)$ & S1 \\
\hline & & & Extremely high $>210$ & S1 \\
\hline & \multirow{7}{*}{ Slope } & \multirow{7}{*}{15} & Level to nearly level (0-1\%) & S1 \\
\hline & & & Very gentle $(1-3 \%)$ & $\mathrm{S} 1$ \\
\hline & & & Gentle $(308 \%)$ & $\mathrm{S} 2$ \\
\hline \multirow[t]{4}{*}{2} & & & Moderate $(8-15 \%)$ & S3 \\
\hline & & & Moderately steep (15-30\%) & $\mathrm{N}$ \\
\hline & & & Steep $(30-50 \%)$ & $\mathrm{N}$ \\
\hline & & & Very steep $(>50 \%)$ & $\mathrm{N}$ \\
\hline \multirow{14}{*}{3} & \multirow{14}{*}{ Land forms } & \multirow{14}{*}{10} & Dissected hill top & $\mathrm{N}$ \\
\hline & & & Subdued hills & $\mathrm{N}$ \\
\hline & & & Linear ridge & $\mathrm{N}$ \\
\hline & & & Scarp slope & $\mathrm{N}$ \\
\hline & & & Isolated mounds & $\mathrm{N}$ \\
\hline & & & Dissected hills & $\mathrm{N}$ \\
\hline & & & Subdued plateau & S3 \\
\hline & & & S. buried pediment & $\mathrm{S} 2$ \\
\hline & & & Moderately buried pediment & S2 \\
\hline & & & Deeply buried pediment & S1 \\
\hline & & & Narrow valleys & S1 \\
\hline & & & Broad valley floors & S1 \\
\hline & & & Aggraded valley fills & S1 \\
\hline & & & Shallow $(25-50 \mathrm{~cm})$ & S3 \\
\hline \multirow[t]{2}{*}{4} & \multirow[t]{2}{*}{ Soil depth } & \multirow[t]{2}{*}{15} & Moderately deep $(75-100 \mathrm{~cm})$ & $\mathrm{S} 2$ \\
\hline & & & Very deep $(>100)$ & S1 \\
\hline \multirow{3}{*}{5} & \multirow{3}{*}{$\begin{array}{l}\text { Surface } \\
\text { drainage }\end{array}$} & \multirow{3}{*}{10} & Moderately well & S2 \\
\hline & & & Well & S3 \\
\hline & & & Sandy loam & S2 \\
\hline \multirow{3}{*}{6.} & \multirow{3}{*}{$\begin{array}{l}\text { Soil texture } \\
\text { (particle size) }\end{array}$} & \multirow{3}{*}{10} & Clay loam & S1 \\
\hline & & & Sandy clay loam & $\mathrm{S} 2$ \\
\hline & & & Clayey & S1 \\
\hline \multirow{4}{*}{7} & \multirow{4}{*}{$\mathrm{pH}$} & \multirow{4}{*}{5} & Moderately acidic (4.5-5.5) & S2 \\
\hline & & & Slightly acidic (5.5-6.5) & S1 \\
\hline & & & Neutral $(6.5-7.5)$ & $\mathrm{S} 2$ \\
\hline & & & Slightly alkaline (7.5-8.5) & S3 \\
\hline \multirow{3}{*}{8} & \multirow{3}{*}{$\mathrm{CEC}$} & \multirow{4}{*}{5} & $10-20 \mathrm{cmol} / \mathrm{kg}$ & S3 \\
\hline & & & $20-30 \mathrm{cmol} / \mathrm{kg}$ & S1 \\
\hline & & & $>30 \mathrm{cmol} / \mathrm{kg}$ & S1 \\
\hline & & & Moderate $(<0.75 \%)$ & $\mathrm{S} 2$ \\
\hline 9 & $\mathrm{OC}$ & 10 & $\operatorname{High}(0.75-1.0 \%)$ & S1 \\
\hline & & & Very high $(>1.0 \%)$ & $\mathrm{S} 1$ \\
\hline & & & Nil & S1 \\
\hline 10 & $\begin{array}{l}\text { Salinity } \\
\text { (FCe }(d S / m)\end{array}$ & 5 & Slight & $\mathrm{S} 2$ \\
\hline & & & Strong & S3 \\
\hline
\end{tabular}

Note: $\mathrm{S} 1=$ Highly suitable; $\mathrm{S} 2=$ Moderately suitable; $\mathrm{S} 3=$ Marginally suitable; $\mathrm{N}=$ Not suitable 
shallow weathered pediments and deeply weathered pediments are slightly acidic ( $\mathrm{pH} 5.5-6.5)$ to neutral $(\mathrm{pH}$ 6.57.5 ) and cover of 47.7 and $10.3 \%$, area respectively. The soils on the aggraded valley fills are slightly alkaline (7.58.5 ) occupy about $20.4 \%$ area. The $\mathrm{pH}$ of the soils decreased with increasing altitude. The soils are very low in soluble salt concentration with EC values of $0.2 \mathrm{dSm}^{-1}$ (Table 2) and have no salinity hazards. The organic carbon (OC) content in the soils ranged from 0.3 to $1.8 \%$ (Table 2 ). The soils developed on dissected hills have relatively more OC than other soils, may be due to forest cover

Cation exchange capacity (CEC) of soils varies from 10.5 to $51.5 \mathrm{cmol}\left(\mathrm{p}^{+}\right) \mathrm{kg}^{-1}$ (Table 2). These high values of $\mathrm{CEC}$ are attributed to the smectite type of clay minerals and high amount of clays. Total exchangeable bases $\left(\mathrm{Ca}^{2+}, \mathrm{Mg}^{2+}\right.$, $\mathrm{Na}^{+}$and $\mathrm{K}^{+}$) contributes near about $90 \%$ of CEC of these soils. Presence of these bases in sufficient quantity in the soils is favourable for plant growth. Calcium is the dominant cation followed by magnesium, sodium and potassium. It varied from 5.4 to $41.0 \mathrm{cmol}\left(\mathrm{p}^{+}\right) \mathrm{kg}^{-1}$. The dominance of $\mathrm{Ca}^{2+}$ may be due to basaltic parent material, which is the source of high calcium. Magnesium varide from 1.1 to $7.7 \mathrm{cmol}\left(\mathrm{p}^{+}\right)$ $\mathrm{kg}^{-1}$ (Table 2). The base saturation ranged from 52.6 to $98.0 \%$ (Table 2). .

\section{Suitability analysis for rice}

The rating and criteria used for suitability evaluation are presented in Table 3 and

The analysis for rice suitability indicates that the level to nearly level (0-1\%) slopes to gentle (1-3\%) slopes, very deep soils and slightly acidic soils qualifies as highly suitable' with an area of $45.52 \%$ of TGA (Fig.2 and Table 5). Gently sloping (3-8\%), moderately deep soils, neutral and moderately acidic soils are moderately suitable with an area of $24.04 \%$ of TGA. The moderately sloping (8-15\%), shallow and slightly alkaline soils are marginally suitable with an area of $0.12 \%$ of TGA. The moderately steep slopes (15-30\%), steep slopes (30-50\%), very steep slopes $(>50 \%)$, dissected hills, subdued hills, scarp slopes, linear ridges soil are not suitable with $24.2 \%$ of TGA.

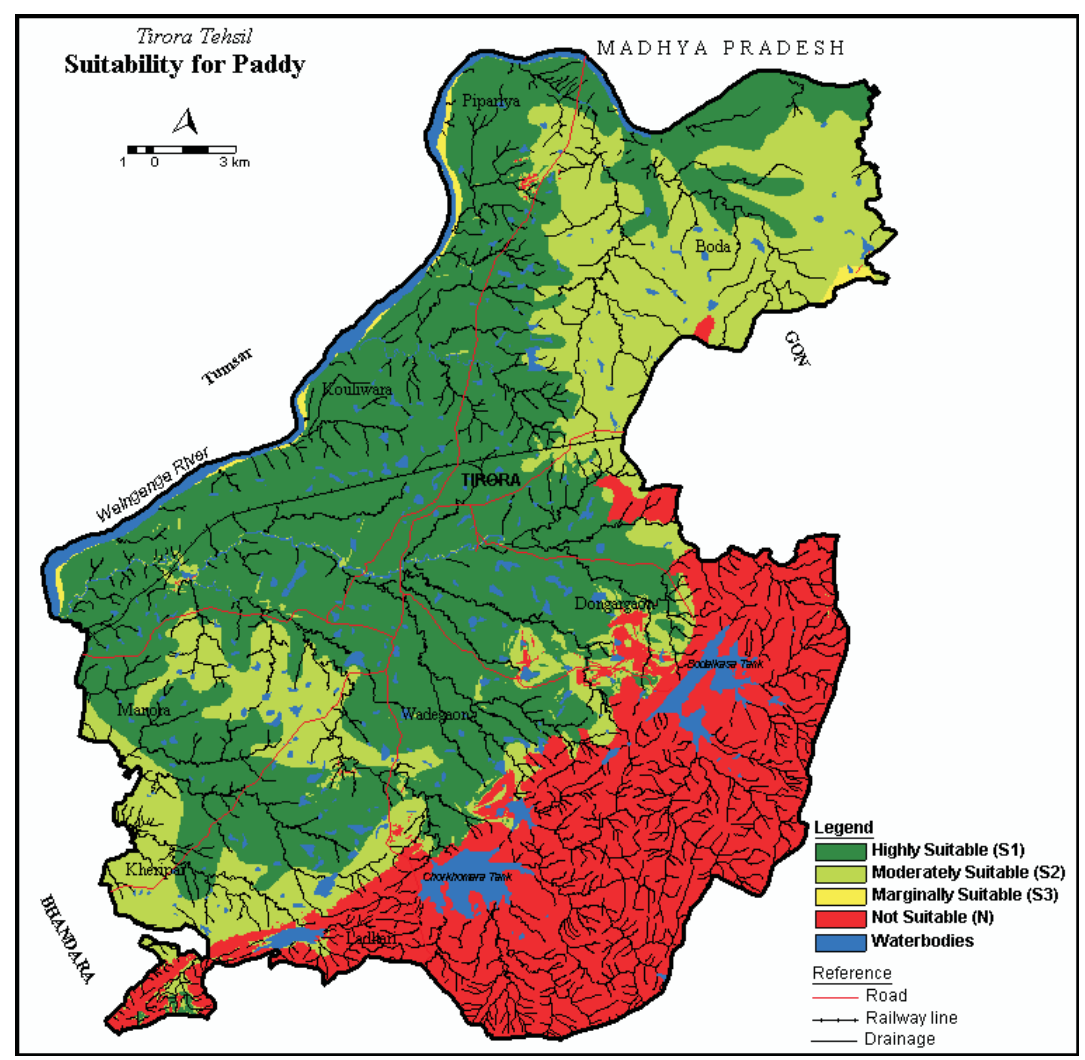

Fig.2 Rice suitability map of Tirora tehsil 
Table 5. Area under different suitability for rice of the Tirora tehsil

\begin{tabular}{clrr}
\hline S.No. & Suitability for rice & \% Area & Area (Sq. km) \\
\hline 1 & Highly suitable & 45.52 & 280.90 \\
2 & Moderately suitable & 24.04 & 148.35 \\
3 & Marginally suitable & 0.12 & 0.75 \\
4 & Not suitable & 24.23 & 149.52 \\
5 & Water bodies & 6.09 & 37.58 \\
6 & Total & 100.00 & 617.10 \\
\hline
\end{tabular}

\section{Conclusions}

The study demonstrates the capabilities of remote sensing data in soil resource inventory and subsequent modeling in GIS for crop suitability evaluation. Integration of relevant thematic database using crop suitability modeling in GIS is of immense help to obtain better and faster results to suggest suitable land use options. Crop suitability models in GIS facilitate to combine weighted layers into a single layer depicting varying suitability of areas of interest. The study indicates that about $45.5 \%$ of TGA in the tehsil is highly suitable, $24.0 \%$ is moderately suitable and $24.2 \%$ of TGA is not suitable for rice cultivation.

\section{References}

Baja, S., Chapman, M.D. and Dragonvich, D. (2002) A conceptual model for defining and assessing land management units using a fuzzy modeling approach in GIS environment. Environmental Management 29, 647-661.

Bin, Q., Jian, Z.H., Lin, C.S., Romkens, M.J.M. and Cheng, L.B. (2007) Land Suitability Assessment and Land Use Change in Fujian Province, China. Pedosphere 17, 493-504.

Bobade, S.V., Bhashkar, B.P., Gaikwad, M.S., Raja, P., Gaikwad, S.S., Anantawar, S.V., Patil, S.V., Singh, S.R. and Maji, A.K. (2010) A GIS based land use suitability assessment in Seoni district, Madhya Pradesh, India. Tropical Ecology 51, 45-54.

Burrough, P.A. (1989) Fuzzy mathematical methods for soil survey and land evaluation. Journal of Soil Science 40, 477-492.

Davidson, D.A., Theocharopoulos, S.P. and Bloksma, R.J. (1994) A land evaluation project in Greece using GIS and based on Boolean and fuzzy set methodologies. International Journal of Geographical Information, 8, 369-384.

Dengiz, O. (2013) Land suitability assessment for rice cultivation based on GIS modeling. Turkish Journal of Agriculture and Forestry 37: 326-334.

Eswaran, H., Vurnabu, S.M. and Spivey, L.D. Jr. (1993) ASSA Spl. Publ. 56, A.S.S.A., USA.

FAO. (1976) A frame work for land evaluation. FAO soils Bull. No. 32, Rome, 72p.

Gangopadhyay, S.K., Reddy, G.P.O., Sarkar, D., Srinivas, C.V. and Khan, I.Q (2010) Soil suitability evaluation using remotely sensed data and GIS- A case study from semi-arid tropics of India, International Journal of Geoinformatics, 6, 35-47.

Halder, J.C. (2013) Land suitability assessment for crop cultivation by using remote sensing and GIS, Journal of Geography and Geology, 5, 65-74.

Jackson, M.L. (1973) Soil chemical analysis. Prentice hall India Pvt. Ltd., New Delhi.

Kihoro, J., Njoroge J.B. and Murage, H. (2013) Suitability analysis for rice growing sites using a multi-criteria evaluation and GIS approach in great Mwea region, Kenya Springer Plus 2, 265-274.

Maji, A.K. (1992) A computerized approach for physical suitability evaluation of lands of Shinglik subwatershed Sikkim. Agropedology 2, 37-44.

Maji, A.K. (1992a) Economic suitability evaluation of lands using ALES programme. Journal of the Indian Society of Soil Science 40, 527-533.

Maji, A.K., Reddy, G.P.O., Tamgadge, D.B. and Gajbhiye K.S. (2005) Spatial modeling for crop suitability analysis using AGROMA software. Asian Journal of Geoinformatics 5, 47-56.

Maji, A.K., Srinivas, C.V., Dubey, P.N., Reddy, G.P.O., Kamble, K. and Velayutham (2002) Soil resource 
information system in GIS environment for land use planning in mountainous regions. Journal of Geographical Information System, India 11, 13-16. Maji. A.K. and Krishna, N.D.R. (1996) Application of geographical information system in soil resource management. Agropedology 6, 75-78.

Malczewski, J. (2004) GIS based land use suitability analysis; a critical overview. Programme Planning 62, 3-65.

PCI (2000) SPANS Ver. 7.2, GIS software, PCI, Ontaria, Canada.

Reddy G.P.O., Nagaraju, M.S.S., Ramteke, I.K., and Sarkar, D. (2013) Terrain Characterization for soil resource mapping in part of semi-tract of Central India using high resolution satellite data and GIS, Journal of the Indian Society of Remote Sensing 41, 331-343.

Reddy, M.G.R., Reddy, G.P.O., Maji, A.K and Rao, K.N. (2004) Land evaluation for cotton suitability in a part of eastern Maharashtra Plateau using remote sensing and GIS. Agropedology 14, 25-31.

Richards, L.A. (1954) Diagnosis and improvement of saline and alkali soils. Agricultural Handbook No. 60, USDA, Washington, D.C. 160.

Rossister, D.G. (1996) A theoretical frame work for land evaluation. Geoderma 72,165-190.
Rossiter, D.G. (1990) ALES: A Framework for Land Evaluation Using a Microcomputer. Soil Use Manage. 6, 7-20.

Saxena, R.K., Verma, K.S., Chary, G.R., Srivastava, R. and Barthwal, A.K. (2000) IRS-1C Data application in watershed characterization and management. International Journal of Remote Sensing 21, 31973208

Soil Survey Staff (1999) Keys to Soil Taxonomy. $8^{\text {th }}$ Ed. SCS USDA: Washington, D.C.

Srivastava, R. and Saxena, R.K. (2004) Technique of largescale soil mapping in basaltic terrain using satellite remote sensing data. International Journal of Remote Sensing 25, 679-688.

Vishakha, T.D., Reddy, G.P.O., Maji,A.K. and Ramteke, I.K. (2013) Characterization of landforms and soils in complex geological formations - A remote sensing and GIS approach, Journal of The Indian Society of Remote Sensing 41, 91-104.

Walke, N., Reddy, G.P.O., Maji, A. K., Thayalan, S. (2012) GIS-based multicriteria overlay analysis in soilsuitability evaluation for cotton: A case study in the black soil region of Central India. Computers and Geosciences 41, 108-118.

Zink, J.A. and Valenzuela, C.R. (1990) Soil-geographic database; structure, application examples. ITC Journal 3, 270-279.

Received : August 2015

Accepted : April, 2016 